\title{
PERSEMBAHAN BAHASA OBJEK DALAM KAMUS DEWAN DAN KAMUS BESAR BAHASA INDONESIA
}

\author{
Oi Chin Chong ${ }^{1}$ \\ Vijayaletchumy a/p Subramaniam ${ }^{2}$ \\ Fakulti Bahasa Moden dan Komunikasi, Universiti Putra Malaysia \\ ${ }^{1}$ chongoichin@gmail.com \\ ${ }^{2}$ letchumy1617@gmail.com
}

\begin{abstract}
Abstrak
Kajian ini menganalisis cara mempersembahkan bahasa objek menerusi Kamus Dewan Edisi Keempat (KD4) (2010), dan Kamus Besar Bahasa Indonesia Edisi Keempat (KBBI4) (2011). Pengkaji menggunakan kerangka prinsip-prinsip umum leksikografi dengan berpandukan pendapat Béjoint (1994) untuk menghuraikan kaedah yang digunakan oleh para penyusun kamus dalam mempersembahkan bahasa objek kedua-dua buah kamus ekabahasa. Dalam kajian ini, 1087 entri telah dipilih secara rawak mudah dan bersistematik. Kaedah kajian pula ialah kaedah kepustakaan dan analisis kandungan dengan huraian secara deskriptif asas. Objektif kajian adalah untuk menganalisis cara bahasa mempersembahkan bahasa objek terhadap KD4 dan KBBI4. Hasil kajian mendapati bahawa kedua-dua buah kamus tersebut mengikut kaedah peraturan atau formula, dan teknik mampatan. Namun, kesemua data kajian tidak menunjukkan penggunaan cara kesejadian atau keidiomatikan bahasa. Kelebihan hasil analisis ini adalah dapat membantu para penyusun kamus memperbaiki kualiti sesebuah kamus yang tepat dengan golongan sasarannya khususnya kamus ekabahasa Melayu yang sedia ada.
\end{abstract}

Kata kunci: kamus ekabahasa, bahasa objek, kaedah peraturan/formula, teknik mampatan, leksikografi

\section{PRESENTATION OF OBJECT LANGUAGE IN KAMUS DEWAN AND KAMUS BESAR BAHASA INDONESIA}

\begin{abstract}
This study analyzes the presentation of object language through Kamus Dewan, $4^{\text {th }}$ Edition (KD4) (2010), and Kamus Besar Bahasa Indonesia, $4^{\text {th }}$ Edition (KBBI4) (2011). The researcher uses the framework introduced by Béjoint (1994) to describe the methodologiess used by the compilers of dictionaries in the language of objects presented in two selected monolingual dictionaries. In this study, 1087 entries were chosen randomly and systematically. Method is the method of literature review and
\end{abstract}


content analysis are described in the basic descriptive. The objective of the study is to analyze how language presents the objects language to KD4 and KBBI4. The results showed that both the dictionary by rule or formula and compression techniques. But all study data do not show how to use nativism or idiomatic language. The advantage of this analysis is to help the lexicographer improve the quality of a proper dictionary with the right to target particular groups, especially among the Malay monolingual dictionaries already available.

Keywords: monolingual dictionary, object language, methods of rule/formula, compression techniques, lexicography

\section{Pendahuluan}

KD4, dan KBBI4 ialah kamus ekabahasa Melayu yang berbentuk umum. Bahasa objek dan metabahasanya adalah menggunakan bahasa yang sama, iaitu Bahasa Melayu. Justeru, para penyusun kamus mempunyai kaedah atau cara bahasa yang tersendiri semasa mempersembahkan kandungan dalam bahasa objek sesebuah kamus ekabahasa. Pelbagai pendapat telah dikemukakan sama ada dari sudut praktik mahupun teori mengenai kandungan yang sepatutnya terdapat dalam sesebuah kamus ekabahasa. Umumnya, kaedah penyusunan sesebuah kamus yang baik seharusnya bersesuaian dengan kehendak sasaran atau pengguna kamus. Himpunan perbendaharaan yang diliputi, teknik pemerian dan penyajian yang kemas dan tuntas, serta reka bentuk kamus yang canggih merupakan faktor penting keberhasilan sesebuah kamus.

Komponen utama dalam sesebuah kamus terbahagi kepada dua bahagian iaitu, kata entri dan pemerian takrif. Aspek pemerian takrif merupakan aspek yang penting dalam peringkat penyusunan kamus. Aspek ini merupakan unsur penentu ketinggian mutu dan kualiti sesebuah kamus. Pada tahap ini, para penyusun kamus haruslah menguasai ilmu teras yang mendalam, khususnya dari segi semantik dan pragmatik, disertai dengan penguasaan ilmu bantu yang lain. Seperti kata Asmah Haji Omar (1984), tugas kamus ialah memberi makna atau takrif kepada kata, dan pentakrifan ini adalah dengan menggunakan kata-kata juga. Oleh itu, bidang perkamusan tidak mempunyai cara lain melainkan memberi makna kepada sesuatu lambang dengan menggunakan lambang itu sendiri (Zuraini Ramli, 2006).

Selanjutnya, pemberian takrif atau pemerian entri termasuk dalam struktur mikro leksikografi dalam komen makna. Hausmann dan Wiegand (1989: 343) menyifatkan struktur mikro kamus banyak berasaskan kerangka sistem maklumat linguistik yang komprehensif. Pemerian entri merupakan komponen teras dalam keseluruhan deskripsi entri. Kaedah mentakrif pada asasnya bermakna tepat, ringkas lagi padat untuk menjelaskan atau merumuskan makna perkataan, istilah, konsep tertentu. Sejak itu, wujud kerjasama yang erat antara bidang leksikografi terutama kaedah mentakrif dengan linguistik (Dorozewski: 1973, 35). Sesungguhnya, pentakrifan sesuatu entri bukan suatu tugas yang mudah. Seseorang pekamus perlu menguasai ilmu teras dalam bidang leksikologi dan terampil menguasai disiplin leksikografi. Hal ini bersesuaian dengan konsep leksikografi yang merupakan seni 
merakam hasil kajian leksikologi dalam bentuk kamus (Newell, 1995) dan bidang ini menuntut penguasaan yang mendalam dalam pelbagai disiplin ilmu.

Justeru, untuk mempersembahkan kandungan dalam bahasa objek iaitu pemberian takrif atau pemerian makna yang seharusnya ada dalam sesebuah kamus, para penyusun kamus mempunyai caranya yang tersendiri atau berbeza antara satu sama lain. Bahasa yang digunakan dalam konteks penyusunan kamus ialah bahasa tersebut bukanlah bahasa biasa. Namun, sebaliknya para penyusun kamus mempunyai cara-cara yang tersendiri yang harus digunakan oleh mereka dalam proses penyusunan sesebuah kamus ekabahasa Melayu. Penyusun kamus boleh menggunakan pelbagai bahan rujukan seperti kamus yang sedia ada, daftar istilah dan sebagainya untuk mencari maksud sesuatu perkataan. Antara cara mempersembahkan kandungan dalam bahasa objek sesebuah kamus berpandukan prinsip umum leksikografi (Béjoint, 1994) ialah mengikut peraturan atau formula tertentu, menggunakan teknik mampatan, dan mengikut kesejadian atau keidiomatikan bahasa.

\section{Pernyataan Masalah}

Kajian ini membincangkan masalah ketiadaan kajian-kajian lepas yang menyatakan cara bahasa mempersembahkan bahasa objek. Umpamanya, kajian Toyud Pomogunan (2007) menyatakan bahawa kerja penyusunan kamus Melayu harus memberikan segala maklumat. Entri yang terpilih pula harus menggambarkan cakerawala budaya dunia Melayu yang luas. Kajian beliau juga mengatakan bahawa setiap entri dalam kamus harus mempunyai maklumat seperti kelas kata, etimologi, sebutan, dan maklumat nota pengguna. Tambahan pula, kupasan daripada Sunduvan Tanak (2007) yang mengemukakan pendapat beliau yang seolah-olah tercabar untuk membuktikan bahawa ilmuwan tempatan mampu untuk menghasilkan kajian yang lebih baik daripada penulis Barat. Selanjutnya, hasil daripada temu bual Uthaya Sankar SB (2007) dengan Harjit Singh Hullon yang menyarankan masyarakat tanpa mengira usia, pangkat, pekerjaan dan latar pendidikan perlu menjadikan Kamus Dewan sebagai kawan yang paling akrab, dan merujuk Kamus Dewan untuk memastikan apa-apa yang kita tulis betul dan tepat. Akhir sekali, artikel Mohamad Sofee Razak (2008) tentang koleksi unggul kamus-kamus ini dapat meningkatkan mutu dan keberkesanan bahasa Melayu di persada dunia. Oleh itu, institusi perkamusan di Malaysia perlu diperkasakan, dan tidak boleh berhenti kerana tabiat bahasa Melayu yang terus berkembang, bersifat terbuka serta mesra bahasa asing. Kesemua kajian di atas telah menambah ilmu mengenai perkamusan secara umumnya. Namun, analisis cara bahasa mempersembahkan bahasa objek tidak dikaitkan oleh kajian mereka. Pengkaji-pengkaji tidak memasukkan contoh entri dalam kamus sebagai kajian mereka. Justeru, kekurangan ini telah memberi lompang kepada penyelidik untuk manganalisis apakah kaedah atau cara bahasa yang bersesuaian untuk mempersembahkan bahasa objek dalam KD4, dan KBBI4? 


\section{Objektif Kajian}

Untuk menganalisis cara bahasa mempersembahkan bahasa objek terhadap keduadua buah kamus ekabahasa Melayu.

\section{Kepentingan Kajian}

Menerusi hasil dapatan, penganalisisan kaedah atau cara bahasa mempersembahkan bahasa objek terhadap KD4, dan KBBI4 adalah penting untuk persoalan format, kekaburan makna, ketaktepatan dan ketidaksesuaian fakta tidak berlaku. Setelah mengenal pasti kaedah-kaedah dalam proses penyusunan kedua-dua buah kamus ekabahasa tersebut, hasil kajian ini bukan sahaja boleh dijadikan sebagai sumber rujukan dan maklumat kepada institusi Dewan Bahasa dan Pustaka, Kuala Lumpur, Malaysia, bahkan juga untuk Pusat Bahasa, Jakarta yang berfokus dalam bidang leksikografi khasnya proses penyusunan kamus ekabahasa Melayu.

\section{Latar Belakang Kajian}

Menurut Béjoint (1994), sekiranya kamus yang dihasilkan ingin membantu pengguna dalam pengekodan bahasa; maka, bukan hanya maklumat sintaksis atau peraturan tatabahasa yang perlu diserlahkan dalam kamus tersebut. Maklumat lain yang sama pentingnya dan amat diperlukan oleh pengguna ialah maklumat kolokasi, maklumat tentang keidiomatikan dan kesejatian bahasa, serta sebarang maklumat yang dapat membantu menghasilkan teks yang dapat diterima oleh seseorang penutur asli. Jika sesuatu definisi itu difahami oleh pengguna, ini bukan sahaja disebabkan kata entri (definiendum), dan definisi (definiens) mempunyai kandungan semantik yang sama tetapi juga kerana definisi lebih mudah difahami daripada kata entri. Sebagai maklumat lanjutan, beliau menyarankan tiga prinsip umum yang terdapat dalam metabahasa. Pertama, bahasa yang digunakan untuk memerikan kesemua butir leksikal bahasa objek yang dipilih sebagai entri kamus. Kedua, cara bahasa ini mempersembahkan maklumat linguistik dan luar linguistik bahasa objek, dan ketiga, konvensi-konvensi leksikografi yang digunakan untuk mempersembahkan kesemua maklumat tersebut.

Bagi Hartmann (1993), beliau menyenaraikan prinsip, dan amalan dalam bidang leksikografi. Beliau turut membincangkan metabahasa leksikografi secara umum, dan ringkas. Beliau mendefinisikan metabahasa sebagai bahasa untuk menangani dan mempersembahkan maklumat bahasa. Seterusnya, beliau membincangkan leksem yang merupakan unit asas yang terdiri daripada bentuk fonetik dan kandungan semantik, tetapi tidak dapat berfungsi sendiri. Leksem terdiri daripada unsur-unsur yang lebih kecil, dan fonem, grafem, suku kata, dan morfem. Leksem ini tersisip dalam konteks yang lebih besar iaitu frasa, klausa, ayat, dan perenggan yang merupakan sebahagian daripada konteks lakuan bahasa dan genre luar linguistik yang lebih luas. Terdapat dua kerangka pilihan untuk menunjukkan hubungan tersebut iaitu kerangka linguistik dan kerangka semiotik. Kedua-dua kerangka ini sudah memadai untuk menunjukkan penggunaan prinsip umum leksikografi. 
Selain itu, Newell (1995) menghuraikan panduan yang perlu ada dalam bidang leksikografi dengan merujuk kepada bahasa Ifugao di Filipina. Penulisan beliau juga menyatakan bahawa metabahasa ialah bahasa yang digunakan untuk memerikan butir leksikal bahasa objek dalam kamus. Bagi kamus ekabahasa, bahasa objek dan metabahasanya adalah penggunaan bahasa yang sama, manakala bagi kamus pelbagai bahasa, bahasa objek dan metabahasa adalah bahasa yang berbeza. Dari segi peratusan kandungan dalam metabahasa mahupun peranan dalam persembahan makna, definisi atau keterangan leksikallah yang merupakan bahagian metabahasa yang paling utama dan penting.

Tambahan pula, Nor Azizah Abu Bakar (2000) mampu membincangkan beberapa aspek metabahasa yang melibatkan kajian bahasa objek, dan pengungkapan definisi dalam perkamusan Melayu yang selama ini dianggap terlepas daripada perhatian pengguna kamus, pengkaji ataupun pengkritiknya. Sebenarnya, banyak persoalan tentang bahasa objek yang merupakan salah satu aspek penting dalam metabahasa boleh dibincangkan dalam leksikografi. Hal ini disebabkan oleh segala maklumat mengenai bahasa objek sesebuah kamus adalah terkandung dalam metabahasa.

\section{Metodologi}

Kerangka kajian ini adalah berdasarkan penggunaan prinsip-prinsip umum leksikografi dengan berpandukan ulasan Béjoint (1994). Beliau telah menyarankan tiga prinsip umum leksikografi. Namun, kajian ini akan menggunakan prinsip kedua iaitu cara bahasa mempersembahkan maklumat linguistik dan luar linguistik bahasa objek ataupun cara memperkatakan bahasa objek. Kajian ini memfokuskan tiga cara bahasa mempersembahkan bahasa objek dalam kedua-dua buah kamus ekabahasa Melayu. Data kajian ini adalah sebanyak 1087 entri daripada kedua-dua buah kamus tersebut yang dipilih secara manual dan sistematik dengan menggunakan kaedah pensampelan rawak mudah (random sampling). Kaedah kajian ini ialah kaedah kepustakaan dan kaedah analisis kandungan. Alat kajian pula terdiri daripada KD4 tahun 2010 terbitan DBP, Kuala Lumpur, Malaysia; dan KBBI4 tahun 2011 terbitan PT Gramedia Pustaka Umum, Jakarta, Indonesia. Analisis data adalah berbentuk kualitatif dan kuantitatif (peratusan asas).

\section{Dapatan Kajian}

Menurut Béjoint (1994), terdapat tiga cara atau kaedah mempersembahkan kandungan dalam bahasa objek sesebuah kamus. Tiga cara tersebut ialah mengikut peraturan atau formula tertentu, menggunakan teknik mampatan, dan mengikut kesejadian atau keidiomatikan bahasa.

\section{Peraturan atau Formula Tertentu}

Semua penyusun kamus bersetuju bahawa pekerjaan mendefinisikan entri atau bahasa yang memperkatakan bahasa objek merupakan salah satu kegiatan perkamusan yang amat rumit. Semua buku yang membincangkan bidang 
perkamusan memberi tekanan kepada aspek membuat definisi (Nik Safiah Karim, 1994).

Mengikut Landau (1984), semua kamus disusun berdasarkan bahasa sebagaimana yang digunakan oleh masyarakatnya. Menurut Nor Azizah Abu Bakar (2000), bahasa yang mempersembahkan atau memperkatakan bahasa objek ini bersifat luar biasa, ditulis mengikut peraturan atau formula tertentu, terlalu ringkas, kadang-kala terputus-putus, jarang sekali mengendahkan keidiomatikan bahasa tabii, dan memaparkan pola struktur yang berulang-ulang secara terancang. Di samping itu, beberapa pertimbangan lain juga perlu diambil kira seperti memberi keutamaan kepada teras makna sesuatu entri.

Berdasarkan analisis pengkaji terhadap jumlah entri (1087) dalam kedua-dua buah kamus tersebut, didapati konteks penyusunan kamus berkenaan telah mengikut peraturan dan menggunakan kaedah tersebut. Hal ini kerana KD4, dan KBBI4 merupakan kamus ekabahasa Melayu yang berbentuk umum dan khasnya untuk para penutur asli. Mengikut Landau (1984) yang menegaskan bahawa huraian sesuatu entri harus mengelakkan definisi yang berbelit-belit atau yang tidak masuk akal. Sebaliknya perlu mengikut peraturan dan formula tertentu. Formulanya ialah pemerian entri dengan menggunakan bahasa bersifat luar biasa, terlalu ringkas, terputus-putus atau pola struktur yang berulang-ulang secara terancang. Oleh sebab kesemua data kajian adalah mengikuti peraturan atau formula tertentu, salah satu contoh entri adalah seperti berikut:

Contoh 1

kelip-kelipIl sj kertas berkilat (berwarna emas, perak, dII) yg dibuat perhiasan, jemeki, kida-kida, labuci.

(KD4, 2010, p. 560)

${ }^{2}$ ke.lip-ke.lip $n$ kertas emas (perak dsb) untuk perhiasan; kida-kida; loberci; jemeki

(KBBI4, 2011, p. 22)

Berdasarkan analisis Contoh 1 'kelip-kelip II/2ke.lip-ke.lip', terpancar secara jelas bahawa para penyusun KD4 dan KBBI4 telah mengikut peraturan dan formula tertentu. Dapatan menunjukkan bahawa penekanan penyusun kedua-dua buah kamus ekabahasa tersebut terhadap pemerian makna Contoh 1 adalah menggunakan bahasa yang mudah, terputus-putus, dan senang difahami iaitu " $s j$ kertas berkilat (berwarna emas, perak, dII) yg dibuat perhiasan (KD4), kertas emas (perak dsb) untuk perhiasan (KBBI4). Selain penggunaan bahasa mudah, kata entri ini juga menggunakan bahasa yang terlalu ringkas iaitu dengan memasukkan kata sinonim seperti "jemeki, kida-kida, labuci" (KD4, 2010, p. 560) dan "kida-kida; loberci; jemeki" (KBBI4, 2011, p. 22) dalam pemerian maknanya. Justeru, Contoh 1 di atas memenuhi peraturan dan formula tertentu dalam proses penyusunan kamus, penyusun kamus jarang mengendahkan keidiomatikan bahasa tabii. 


\section{Teknik Mampatan}

Menurut Sinclair (dalam Nor Azizah Abu Bakar, 2000) umumnya, sesebuah kamus itu menggunakan teknik mampatan atau 'compression techniques' ketika memperkatakan bahasa objek. Teknik ini memerlukan penyusun kamus mempunyai kemahiran mengekod yang khusus. Teknik mampatan ini bermakna maklumat metabahasa dipersembahkan dengan cara yang padat, singkat, dan jelas (Rujuk Contoh 2). Oleh sebab KD4, dan KBBI4 merupakan kamus umum, justeru pemerian bahasa objeknya perlu menggunakan konsep atau teknik mampatan maklumat. Berbeza dengan kamus ekabahasa untuk golongan pelajar yang dihuraikan dalam bahasa yang mudah, dan senang difahami oleh para pelajar. Kaedah ini mempunyai dilemanya kerana penggunaan ruang yang banyak untuk memerikan sesuatu kata entri.

Biasanya, lebih banyak kategori maklumat dalam kamus, lebih termampatlah maklumat metabahasanya. Para pengguna kamus perlu mendapatkan keseluruhan maklumat yang penting, dan termampat dalam sesebuah kamus ekabahasa. Maklumat linguistik, dan maklumat bukan linguistik dapat dimampatkan dalam sesuatu entri kamus merupakan tahap penyusunan kamus yang baik, dan terancang. Kata entri yang termuat dalam sesebuah kamus dibina dengan juraian maklumat yang kukuh, meliputi tanda sebutan, kelas kata, pemerian makna, konteks ayat yang menjadi contoh, angka penanda polisemi dan homonim, pelabelan, dan lain-lain. Kesemua unsur ini mendukung ciri-ciri preskriptif yang jelas dari aspek nahunya, dan ciri-ciri deskriptif yang jelas dari sudut pemerian makna leksikalnya. Sekiranya kesemua maklumat tersebut termuat dalam sesuatu kata entri, maka pemerian makna kata entri tersebut telah menggunakan teknik mampatan dalam proses penyusunan kamus (Rujuk Contoh 2).

Berdasarkan analisis kesemua data dalam KD4, terdapat 16 kata entri yang tidak menggunakan teknik mampatan iaitu penyusun kamus tersebut tidak memasukkan maklumat-maklumat lain selain daripada takrif atau pemerian makna kata entri yang ringkas dan mudah difahami. Paparan data tersebut dalam Jadual 1:

Jadual 1

Kata entri yang tidak menggunakan teknik mampatan dalam KD4

\begin{tabular}{llll}
\hline Bil. & Entri & Pengungkapan Definisi KD4 & HIm. \\
\hline 1. & alternator & pengulang alik & 40 \\
2. & bacang & embacang & 100 \\
3. & bang II & singkatan bagi abang & 120 \\
4. & bibinda & bibi (lebih hormat) & 180 \\
5. & bom II & tempat ayam berlaga di gelanggang & 200 \\
6. & bum I & pekaki layar & 220 \\
7. & bumbun I & pondok kecil tempat pemburu & 220 \\
& & mengintai buruannya & \\
8. & cinda & singkatan bagi cicinda & 280 \\
9. & dolfin & ikan lumba-lumba & 360 \\
10. & kudil & kudis & 840 \\
11. & kuwung & pelangi & 860 \\
\hline & & &
\end{tabular}




\begin{tabular}{llll}
\hline 12. & lancap II & melakukan zina tangan & 880 \\
13. & Nia & leher (baju) & 1080 \\
14. & reca & arca & 1300 \\
15. & singgul & menyondol ke tepi & 1500 \\
16. & warak II & badan & 1800 \\
\hline
\end{tabular}

Selain itu, selebihnya iaitu 1071 kata entri dalam KD4 adalah menggunakan teknik mampatan. Kajian ini hanya akan memaparkan salah satu contoh kata entri yang menggunakan teknik tersebut tanpa memasukkan pelbagai maklumat lain. Paparan entri seperti berikut:

Contoh 2

cambah 1. tumbuhan yg baru keluar dr bijih benih dsb;

$\sim$ kelapa tumbuh kelapa, tombong kelapa, 2. $\mathrm{Kl}, \mathrm{Tr}$ tauge;

bercambah 1. mula tumbuh (bkn bijih benih dsb); 2. mem-

punyai cambah; 3. muncul, terbit, lahir: Minah menjeling

tajam, kemudian juga sebuah senyuman di bibirnya;

usianya yg mendekati empat puluhan dan masih membujang

itu membuatkan suatu harapan, 4. ada banyak, ada (terdapat)

di merata-rata tempat: di surau dan madrasah yg di tanah

air kita ini;

mencambahkan menjadikan bercambah: biji benih;

cambahan munculnya, terbitnya, lahirnya: dia tersenyum,

diulit bibit kelegaan di hatinya;

percambahan perihal bercambah (bijih benih): keinginan utk

mencegah senjata nuklear;

pencambahan perbuatan mencambahkan; $\rightarrow$ kecambah.

(KD4, 2010, p. 240)

Penggunaan teknik mampatan bagi Contoh 2 'cambah' di atas meliputi singkatan lain (yg, dr, dsb, bkn, utk); gabungan kata ( kelapa, biji benih); tanda rujuk silang $(\rightarrow)$; contoh pemakaian leksem (Minah menjeling tajam, kemudian juga sebuah senyuman di bibirnya; usianya yg mendekati empat puluhan dan masih membujang itu membuatkan suatu harapan, di surau dan madrasah yg di tanah air kita ini; keinginan utk mencegah senjata nuklear), angka polisemi leksem (1, 2, 3, 4); dan label etimologi (asal usul kata) seperti (KI, Tr).

Manakala dalam KBBI4, sebanyak 1087 kata entri dalam kamus ini menggunakan teknik mampatan dalam tahap penyusunan kamus berkenaan. Sekurang-kurangnya penyusun kamus memasukkan satu maklumat iaitu penyukuan atau penyebutan kata dalam pemerian makna kata entri dalam kamus ini. Enam entri yang mematuhi teknik tersebut ditunjukkan dalam Jadual 2:

Jadual 2

Kata entri yang memasukkan penyebutan kata dalam KBBI4

\begin{tabular}{lll}
\hline Bil. & Data KBBI4 & HIm. \\
\hline 1. & de.ra.wa lihat gula & 317 \\
\hline
\end{tabular}




\begin{tabular}{lll}
\hline 2. & 'ka.la lihat bintang & 606 \\
3. & ma.rut lihat ${ }^{1}$ carut & 881 \\
4. & sa.min lihat minyak & 1215 \\
5. & sem.pa.dan lihat ketam & 1264 \\
6. & se.pe.nuh lihat daun & 1279 \\
\hline
\end{tabular}

Selanjutnya, jumlah entri lain iaitu sebanyak 1081 adalah memasukkan pelbagai maklumat seperti singkatan lain, label ragam bahasa, label etimologi, angka polisemi leksem, dan sebagainya. Berikut hanya memaparkan salah satu contoh entri yang agak lengkap maklumatnya dalam KBBI4:

Contoh 3

da.dih $n$ air susu sapi, kerbau, dsb yg pekat atau dikentalkan; mengajar orang tua makan--, pb mengajar orang yg lebih pandai;

-- darah Dok darah yg kental; -- jalang Mk (air) susu encer:

-- kering mentega; -- pekat air susu yg kental

(KBBI4, 2011, p. 283)

Penggunaan teknik mampatan bagi Contoh 3 'da.dih' di atas meliputi singkatan lain (dsb, yg); gabungan kata (-- darah, -- jalang, -- kering, -- pekat ); dan label bidang seperti (Dok), peribahasa (mengajar orang tua makan--), dan label etimologi (asalusul kata) seperti $M k$.

Perbezaan entri antara teknik mampatan dan teknik bukan mampatan dapat dilihat dengan jelas melalui Contoh 2 dan Contoh 3 di atas. Entri yang menggunakan teknik mampatan memasukkan sebanyak maklumat mungkin seperti sebutan kata, etimologi, kelas kata dan sebagainya dalam sesuatu entri. Berbeza pula dengan entri yang tidak menggunakan teknik mampatan iaitu entri tersebut tidak memasukkan sebarang maklumat selain pengungkapan definisi.

\section{Kesejadian atau Keidiomatikan Bahasa}

Cara memperkatakan bahasa objek mengikut cara ini telah diperjuangkan oleh Mc Carthy dan Sinclair di England pada tahun 1980-an (dalam Nor Azizah Abu Bakar, 2000). Menurut mereka dalam proses pengekodan, pengguna tidak hanya memilih kata demi kata berpandukan pengetahuan tatabahasa tetapi juga memilih 'ketulan teks' pada sesuatu masa. Ini bermakna selain daripada maklumat sintaksis atau peraturan tatabahasa, penyusun kamus juga perlu menyerlahkan maklumat kolokasi, maklumat keidiomatikan dan kesejadian bahasa, dan sebarang maklumat yang dapat membantu dalam penghasilan teks yang dapat diterima oleh penutur asli (Rujuk Contoh 4).

Pengaruh ahli-ahli leksikografi seperti Sinclair yang memperjuangkan 'the idiom principle' dan Mc Carthy yang mengetengahkan kesejadian bahasa, terdapat dalam kamus ekabahasa bahasa Melayu. Namun demikian, 1087 entri yang dijadikan bahan analisis dalam kajian inti tidak mengikut cara ini. Sungguhpun begitu, pengkaji akan memasukkan contoh lain dalam KD4 yang mengikut kesejadian dan 
keidiomatikan bahasa. Contohnya seperti berikut:

Contoh 4

adat 1. peraturan yg sudah diamalkan turun-temurun (sejak dahulu kala) di dlm sesuatu masyarakat (sehingga merupakan hukum dan peraturan yg harus dipatuhi), lembaga: Minangkabau; Perpatih; Rembau; ...

(KD4, 2010, p. 8)

Jelas kelihatan, untuk menganalisis cara bahasa mempersembahkan bahasa objek terhadap kedua-dua buah kamus ekabahasa Melayu iaitu KD4 dan KBBI4 mempunyai caranya yang tersendiri. Daripada tiga cara yang disyorkan oleh Béjoint (1994), analisis terhadap jumlah data kajian mendapati bahawa kedua-dua buah kamus ekabahasa tersebut hanya menggunakan dua cara iaitu mengikut teknik atau peraturan tertentu dan teknik mampatan. Pengkaji memberikan Contoh 4 "adat", iaitu contoh entri lain dalam KD4 yang mengikut kesejadian atau keidiomatikan bahasa.

\section{Kesimpulan}

Secara ringkasnya, untuk mempersembahkan bahasa objek dalam sesebuah kamus, umumnya proses penyusunan sesebuah kamus menggunakan bahasa yang tersendiri. Pengkaji telah menganalisis cara bahasa mempersembahkan bahasa objek melalui tiga kaedah iaitu kaedah mengikut formula atau peraturan tertentu, teknik mampatan, dan kaedah mengikut kesejadian atau keidiomatikan bahasa. Hasil dapatan terbukti bahawa KD4 dan KBBI4 mengikut formula atau peraturan tertentu, dan teknik mampatan. Entri-entri tersebut telah menggunakan singkatan yang ringkas, kadangkala ayatnya terputus-putus, memaparkan pola struktur yang berulang-ulang, memasukkan kata sinonim dan sebagainya. Kedua-dua buah kamus tersebut cuba memampatkan sebanyak maklumat seperti etimologi, label kelas kata, gabungan kata, contoh penggunaan ayat dan maklumat lain dalam sesuatu entri. Hasil dapatan juga menunjukkan bahawa para penyusun kamus di Malaysia mahupun Indonesia tidak mengikut cara kesejadian atau keidiomatikan bahasa. Namun demikian, pengkaji mendapati entri lain dalam KD4 yang menggunakan kaedah tersebut. Justeru, proses penyusunan KD4 adalah tidak konsisten. Kesimpulannya, kelebihan penghasilan sesebuah kamus ekabahasa Melayu yang berkualiti dan baik adalah bergantung kepada cara bahasa untuk mempersembahkan bahasa objek. Para pengguna pula jangan 'terpengaruh' dengan nama dan gambaran fizikal sesebuah kamus sahaja, malah mereka berhak, dan mampu menilai persembahan maklumat-maklumat dalam kamus tersebut.

\section{Rujukan}

Asmah Haji Omar. (1984). Kaedah pengajaran bahasa. Kuala Lumpur, Malaysia: Dewan Bahasa dan Pustaka. 
Béjoint, H. (1994). Tradition and innovation in Modern English dictionaries. Oxford, England: Oxford University Press.

Doroszewski, W. (1973). Elements of lexicology and semiotics. The Hague, Netherlands: Mouton.

Hartmann, R. R. K. (Pnyt.) (1993). Leksikografi: Prinsip dan amalan. (Zainab Ahmad, Terjemahan). Kuala Lumpur, Malaysia: Dewan Bahasa dan Pustaka.

Hausmann, F. J., \& Wiegand, F. E. (1989). Component Parts and Structures of General Monolingual Dictionaries: A Survey. Dalam F. J. Hausmann et al. Dictionaries: An International Encyclopedia of Lexicography. Berlin \& New York: Walter de Gruyter.

Kamus Besar Bahasa Indonesia Edisi Keempat. (2011). Jakarta, Indonesia: PT Gramedia Pustaka Utama.

Kamus Dewan Edisi Keempat. (2010). Kuala Lumpur, Malaysia: Dewan Bahasa dan Pustaka.

Landau, S. I. (1984). Dictionaries: The art and craft of lexicography. New York, NY: Cambridge University Press.

Mohamad Sofee Razak. (2008). Kamus rakan bahasa paling setia. Jurnal Dewan Bahasa, 8(11), 28-29.

Newell, L. E. (1995). Handbook on lexicography for Philippine and other languages. Manila, Philippines: Linguistic Society of the Philippines.

Nik Safiah Karim. (1994, Disember). Leksikografi Melayu: Beberapa perspektif linguistik. Kertas kerja yang dibentangkan di Seminar Perkamusan Melayu, Kuala Lumpur, Malaysia.

Nor Azizah Abu Bakar. (2000, Jun). Metabahasa dan pengungkapan definisi: Rujukan khusus kepada kamus Melayu. Kertas Kerja yang dibentangkan di Bengkel Leksikografi, Bangi, Malaysia.

Sunduvan Tanak. (2007). Sebuah kamus untuk sebuah rumah. Jurnal Dewan Bahasa, $7(3), 58-59$.

Toyud Pomogunan. (2007). Leksikografi sebagai cabang wahana ilmu. Jurnal Dewan Bahasa, 7(3), 56-57.

Uthaya Sankar SB. (2007). Pencemaran bahasa kamus sebagai sahabat yang akrab. Jurnal Dewan Bahasa, 7(4), 58-62.

Zuraini Ramli. (2006). Buku katan: Satu kajian awal leksikografi Melayu. Jurnal Bahasa, 6(3), 520-540. 